\title{
PENERAPAN AMBANG BATAS SENGKETA HASIL PILKADA PADA PUTUSAN MK NOMOR 14/PHP.BUP-XV/2017
}

\author{
Muhamad Sofian \\ Program Studi Hukum, Fakultas Hukum, Universitas Muhammadiyah Yogyakarta, Indonesia \\ E-mail: muhamad.sofian.2015@law.umy.ac.id
}

\section{Info Artikel}

Diajukan: 26-06-2020

Direview: 18-08-2020

Direvisi: $25-08-2020$

Diterima: 27-08-2020

DOI: $10.18196 / m l s . v 1 i 3.9193$

\section{Abstrak}

Penerapan Ambang Batas Sengketa Hasil Pilkada pada Putusan MK No 14/PHP.BUP-XV/2017 tentang perselisihan Hasil Pemilihan Bupati dan Wakil Bupati Tolikara Tahun 2017, pada penerapannya MK mengenyampingkan ambang batas tersebut. Pengenyampingan tersebut memiliki pertimbangan hukum, serta berimplikasi pada banyak hal. Pembahasan dalam penulisan ini adalah bagaimana penerapan ambang batas sengketa Pilkada serta Implikasi penerapan ambang batas dari Putusan MK No 14/PHP.BUP-XV/2017. Jenis Penulisan penelitian yang digunakan adalah jenis penelitian Normatif, dimana obyek penelitiannya adalah peraturan perundang-undangan dan Putusan MK No 14/PHP,BUP-XV/2017. Teknik analisis data dilakukan secara Prespektif dengan menggunakan metode deduktif, maksudnya, data-data umum, asas-asas hukum, doktrin, dan peraturan perundang-undangan di rangkai secara sistematis sebagai sususan fakta-fakta hukum dalam mengkaji, mengaanalisis Putusan MK Nomor 14/PHP.BUP-XV/2017. Hasil penelitian yang didapatkan bahwa Penerapan ambang batas sengketa hasil pemilihan Bupati dan wakil Bupati Tolikara adalah pertama, Hakim pengenyampingkan ambang Batas sengketa hasil Pilkada sehingga hakim Mahkamah menjatuhkan Putusan Sela. Hakim berpendapat, belum serta merta memberlakukan Pasal 158 karena penyelenggaran pemilihan dinilai cacat hukum, dan rekapitulasi suara yang belum sesuai dengan aturan, Namun pada Putusan Akhir, MK tetap memberlakukan ketentuan Ambang Batas Penyelesaian sengketa Pilkada. Kedua, Implikasi dari penerapan ambang batas sengketa hasil Pilkada pada Putusan MK No 14/PHP.BUP-XV/2017 adalah pengenyampingan Pasal 158 atau ambang batas penyelesaian sengketa Pilkada dan akan berimplikasi pada lembaga MK menjadi lembaga yang megutamakan keadilan subtansif bukan menjadi lembaga kalkulatif. MK menjadi lembaga yang menjaga marwah jalannya demokrasi di Indonesia, lembaga yang melakukan penerobosan hukum dan banyaknya peserta yang mengajukan sengketa ke $M K$.

Kata kunci: ambang batas; mahkamah konstitusi; sengketa pilkada

\section{Pendahuluan}

Pemilihan Kepala Daerah secara demokratis adalah dengan dipilih oleh rakyat secara langsung. Diberikannya hak kepada rakyat untuk memilih secara langsung kepala daerah Gubernur, Bupati atau Walikota artinya negara telah memberikan sarana penyaluran hak asasi warga negara yang sangat prinsipil. Oleh karena itu, demi terwujudnya hak-hak asasi warga negara pemerintah diharuskan untuk menjamin 
terlaksananya pemilihan umum sesuai dengan jadwal ketatanegaraan yang telah ditentukan. ${ }^{1}$

Pemilihan kepala daerah tidak terlepas dari permasalahan-permasalahan, mulai dari permasalahan administratif, tindak pidana Pilkada, perselisihan hasil Pilkada dan masih banyak lagi. Sengketa tersebut banyak ditemukan pasca Pilkada serentak dilaksanakan. Sengketa perselisihan perolehan suara pada pemilihan kepala daerah menjadi yang paling polemik dengan diberlakuaknnya Pasal 158 Undang-Undang Nomor 10 Tahun 2016. Pada pasal tersebut menjelaskan tentang aturan ambang batas perselisihan suara untuk mengajukan sengketa.

Mahkamah Konstitusi menjadi lembaga yang berwenang untuk menyelesaikan sengketa perselisihan hasil Pilkada namun hal tersebut menjadi polemik ketika Pasal 158 memberikan ambang batas terhadap perselisihan hasil suara. Pada Undang-Undang Nomor 10 Tahun 2016 Pasal 158 ada syarat administratif untuk mengajukan gugatan ke Mahkamah Konstitusi, dimana setiap daerah yang mengajukan gugatan harus dihitung jumlah suara Sah kemudian dihitung perbedaan perolehan suara. Pada Pasal 158 menyebutkan bahwa, :

(1) Peserta Pemilihan Gubernur dan Wakil Gubernur dapat mengajukan Permohonan pembatalan penetapan hasil perhitungan suara dengen ketentuan.

a. Provinsi dengan jumlah penduduk sampai 2.000.000 (dua juta) jiwa, pengajuan perselisihan perolehan suara dilakukan jika terdapat perbedaan paling banyak sebesar 2\% (dua persen) dari total suara sah hasil perhitungan suara tahap akkhir yang ditetapkan oleh KPU provinsi

b. Provinsi dengan jumlah penduduk lebih dari 2.000 .000 (dua juta) jiwa, sampai dengan 6.000.000 (enam juta) jiwa pengajuan perolehan suara dapat dilakukan jika terdapat perbedaan paling banyak 1,5\% (satu koma lima persen) dari total suara sah hasil perhitungan suara tahap akhir yang ditetapkan oleh KPU Provinsi.

c. Provinsi dengan jumlah penduduk lebih dari 6.000 .000 (enam juta) jiwa sampai dengan 12.000.000 (dua belas juta) jiwa, pengajjuan perselisihan perolehan suara dilakukan jika terdapat perbedaan paling banyak sebesar $1 \%$ (satu persen) dari total suara sah hasil perhitungan suara tahap akhir yang ditetapkan oleh KPU provinsi

d. Provinsi dengan jumlah penduduk lebih dari 12.000.000 (dua belas juta) jiwa, pengajuan perselisihan perolehan suara dilakukan jika terdapat perbedaan paling banyak sebesar 0,5\% (nol koma lima persen) dari total suara sah hasil perhitungan suara tahap akhir yang ditetapkan oleh KPU Provinsi

\footnotetext{
${ }^{1}$ Asshiddiqie, J. (2013). Pengantar Ilmu Hukum Tata Negara. Jakarta: PT. Raja Grafindo Persada, h. 416.
} 
(2) Peserta Pemilihan Buapti dan Wakil Bupati serta Walikota dan Wakil Walikota dapat mengajukan permohonan pembatalan penetapan hasil perolehan suara dengan ketentuan;

a. Kabupaten/Kota dengan jumlah penduduk sampai dengan 250.00 (dua ratus lima puluh ribu) jiwa, pengajuan perselisihan perolehan suara dilakukan jika terdapat perbedaan paling banyak sebesar $2 \%$ (dua persen) dari total suara sah hasil perhitungan suara tahap akhir yang ditetapkan oleh KPU Kabupaten/Kota.

b. Kabupaetn/Kota dengan jumlah penduduk lebih ari 250.000 (dua ratus lima puluh ribu) jiwa sampai dengan 500.000 (lima ratus ribu ) jiwa, pengajuan perselisihan perolehan suara dilakuakn apabila terdapatb perbedaan paling banyak sebesar 1,5\% (satu koma lima persen) dari total suara sah hasil perhitungan suara tahap akhir yang ditetapkan oleh KPU Kabpupaten/Kota.

c. Kabupaten/Kota dengan jumlah penduduk lebih dari 500.000 (lima ratus ribu) jiwa sampai dengan 1.000.000 (satu juta) jiwa, pengajuan perselisihan perolehan suara dilakukan jika terdapat perpedaan paling banyak sebesar $1 \%$ (satu persen) dari total suara sah hasil perhitungan suara tahap akhir KPU Kabupaten/Kota

d. Kabupaetn/kota dengan jumlah penduduk lebih dari 1.000.000 (satu juta) jiwa, pengajuan perselisihan perolehan suara dilajukan jika terdapat perbedaan paling banyak sebesar 0,5\% (nol koma lima persen) dari total suara sah hasil perhitungan suara tahap akhir KPU Kabupaten/Kota.

Pada kasus ini Mahkamah Konstitusi lebih mengedepankan amanat UndangUndang dan tidak menjadi lembaga kehakiman yang mengedepankan keadilan Subtansif. Pada Penerapan di Putusan Mahkamah Konstitusi No 14/PHP.BUPXV/2017 Tentang Perselisihan Hasil Pemilihan Bupati dan Wakil Bupati Tolikara Provinsi Papua Tahun 2017, Hakim Mahkamah mempertimbangkan ketentuan Pasal 158 Undang-Undang Nomor 10 Tahun 2016 sebelum pertimbangan pokok persoalan. Pertimbangan itu sebagai salah satu syarat apakah permohonan itu dapat diterima atau tidak. Hal ini dikarena Mahkamah Konstitusi akan menghitung jumlah perselisihan hasil pilkada. Akan tetapi Mahkamah Konstitusi tidak serta merta memberlakukan Ambang Batas Pada sengketa ini, kemudian ini menjadi perdebatan tentang diterapkan Pasal 158 oleh Mahkamah Konstitusi. Hal ini kemudian menjadi topik kajian dalam penulisan ini. Bersumber pada Uraian Latar Belakang Masalah tersebut diatas, maka penelitian ini memberikan rumusan masalah adalah Bagaimana Penerapan dan Implikasi Ambang Batas Sengekta Hasil Pilkada Pada Putusan Mahkamah Konstitusi No 14/PHP.BUPXV/2017 Tentang Perselisihan Hasil Pemilihan Bupati dan Wakil Bupati Tolikara Provinsi Papua Tahun 2017 ? 


\section{Metode}

Penelitian ini merupakan penelitian hukum normatif, yang mencakup penelitian terhadap asas-asas hukum, konsep-konsep hukum, putusan serta adanya perabandingan peraturan perundang-undangan yang berkitan dengan analisis yuridis atas suatu Putusan Mahkamah Konstitusi No 14/PHP.BUP-XV/2017. Pada penelitian ini menggunakan metode studi kepustakaan, yakni dengan cara menganalisa dan mempelajari data dan informasi melalui buku, jurnal, artikel ilmiah, perundang-undangan, dan dari berbagai sumber lain. Pada penelitian ini juga dilakukan wawancara dengan ahli sesuai dengan permasalahan pada penelitian ini. Dalam hal ini adalah Dosen dan pejabat yang berwenang dalam Pemilu atau Pilkada. Pengolahan data menggunakan teknik deduktif yaitu data-data umum, doktrin, asas-asas hukum serta adanya Peraturan PerundangUndangan kemudian disusun secara sistematis sebagai susunan fakta-fakta hukum guna mengkaji Implikasi diterapkannya ketentuan ambang batas perselisihan hasil Pemilihan Bupati dan waki bupati Tolikara oleh Mahkamah Konstitusi pada Putusan Mahkamah Konstitusi Nomor 14/PHP.BUP-XV/2017.

\section{Hasil dan Pembahasan.}

\subsection{Penerapan Ambang Batas Sengketa Hasil Pilkada dalam Putusan MK Nomor 14/PHP.BUP-XXV/2017}

\subsubsection{Sengketa Pemilihan Kepala Daerah Kabupaten Tolikara Tahun 2017}

Kabupaten Tolikara merupakan salah satu kabupaten yang ikut serta dalam penyelenggaraan Pemilihan Kepala Daerah serentak tahun 2017. Akan tetapi, pasca penyelanggaraan perhitungan suara dan penetapan perolehan suara oleh KPU Kabupaten Tolikara salah satu pasangan calon mengajukan gugatan ke Mahkamah Konstitusi.

Salah satu pasangan calon Bupati melakukan gugatan ke Mahkamah Konstitusi, sebagai lembaga yang menyelesaikan sengketa Pemilihan kepala daerah. Pada pokok perkaranya, pasangan calon bupati tersebut sebagai pemohon, memberikan keterangan bahwa:

a) Adanya kesalahan pada perhitungan suara. Pada perhitungan suara yang dilakukan oleh KPU Kabupaten Tolikara, menurut pemohon terjadi kesalahan dalam perhitungan. Data perolehan suara antara yang dimiliki oleh pemohon dan termohon berbeda. Tindakan KPU Tolikara yang memaksakan untuk melakukan pemungutan dan perhitungan suara pada 18 Distrik di Kabupaten Tolikara dengan dan tanpa menghiraukan rekomendasi Panwaslu, menyebabkan perolehan suara yang berbeda antara pihak terkait dan pemohon. Pada semestinya hasil perolehan suara di 18 Distrik untuk semua pasangan calon harus di anggap tidak pernah dikarenakan masih menyisakan banyak pelanggaran yang dilakukan oleh KPU Kabupaten Tolikara yang bertentangan dengan peraturan perundang-undangan. 
b) Pelanggaran di 18 Distrik Rekapitulasi dan perhitungan suara yang telah ditetapkan oleh KPU Kabupaten Tolikara pada 18 Distrik adalah tidak Sah dan atau tidak benar menurut hukum dan karenanya harus dibatalkan. Hal ini disebabkan adanya rekomendasi tentang Pemungutan suara Ulang atau PSU dan Pembatalan Hasil Pemungutan Suara untuk Pemilihan Bupati dan Wakil Bupati Tolikara Tahun 2017, dimana rekomendasi tersebut disampaikan kepada KPU Kabupaten Tolikara.

c) Politik Uang/ Money Politic. Politik uang/Money Politic terjadi dibeberapa Distrik antara lain adalah, Distrik Kembu, Distrik Nabunage, Distrik Nunggawi, Distrik Bokoneri, Distrik Telenggeme, Distrik Timori, dan Distrik Anawi.

d) KPU Kabupaten Tolikara tidak mengindahkan surat rekomendasi Panwaslu Tolikara tentang pelaksanaan pemungutan suara ulang. Bawaslu Kabupaten Tolikara melalui Panwaslu memberikan Surat Rekomendasi Panwaslu Kabupten Tolikara Nomor 059/PNWS-KAB-TLK/II/2017 tentang Rekomendasi Pembatalan Hasil Pemungutan Suara dan Pemungutan Suara Ulang Pemilihan Bupati dan Wakil Bupati Tolikara Tahun 2017, yang merekomendasikan ke KPU Kabupaten Tolikara untuk membatalkan hasil pemungutan suara dan pemungutan suara ulang di 18 Distrik, namun rekomedasi tersebut tidak dijalankan oleh KPU Kabupten Tolikara dan tetap melakukan pemungutan dan perhitungan suara.

Mahkamah Konstitusi menguraikan dengan singkat jumlah dan jenis pelanggaran. Adapun pelanggaran tersebut adalah ${ }^{2}$ :

a) Pelanggaran Administrasi Pemilu

Bahwa ada 1 temuan dugaan pelanggaran administrasi yaitu temuan No 01/TM/PWNS-Kab-TLK/PILKADA/II/2017 dan telah diteruskan oleh KPU Kabupaten Tolikara.

b) Pelanggaran Pidana Pemilu

Bahwa ada 2 laporan dugaan money politik yaitu No 01/LP/PWSL-TLK/II/2017 dan Nomor 03/LP/PWSL-KAB.TLK/II/2017 yang telah dikaji oleh panwas dan kepolisian tetapi kejaksaan wamena jayawijaya berpendapat lain sehingga dihentikan

c) Pelanggaran Kode Etik Penyelenggaran Pemilu

(1) Bahwa ada 1 laporan dugaan pelanggaran kode etik yaitu laporan NO 01/LP/PNWS-TLK/PILKADA/XII/2016 yang telah diteruskan ke DKPP dan telah disidangkan tetapi belum ada keputusan DKPP.

(2) Bahwa ada 1 temuan dugaan pelanggaran administrasi yaitu temuan No 01/TM/PWNS-Kab-TLK/PILKADA/II/2017 dan telah diteruskan ke DKPP.

\footnotetext{
${ }^{2}$ Putusan MK No 14/PHP.BUP-XV/2017 Tentang Perselisihan Hasil Pemilihan Buapti Dan Wakil Bupati Tolikara Provinsi Papua Tahun 2017
} 
Sebelum menjatuhkan putusan akhir Mahkamah Konstitusi memberikan Putusan sela. Putusan sela berisi perintah yang harus dilakukan para pihak yang berperkara untuk memudahkan hakim menyelesaikan pemeriksaan perkara, sebelum hakim menjatuhkan putusan akhir. Adapun Putusan sela yang diputuskan Mahkamah Konstitusi adalah sebagai berikut:

(1) Menyatakan Rekapitulasi perhitungan suara yang termaktub dalam Keputusan KPU Kabupaten Tolikara No 09/kpts/KPU-Kab.TLK/II Tahun 2017 tentang Penetapan Rekapitulasi Hasil Perhitungan suara dan Hasil Pemilihan Bupati dan Wakil Bupati Tolikara tahun 2017 adalah cacat hukum.

(2) Menangguhkan untuk berlakunya Keputusan KPU Kabupaten Tolikara No 09/kpts/KPU-Kab.TLK/II Tahun 2017 tentang Penetapan Rekapitulasi Perhitungan Suara dan Hasil Pemilihan Bupati dan Wakil Bupati Tolikara Tahun 2017 yang cacat hukum.

(3) Memerintahkan kepada KPU provinsi Papua untuk menyelenggarakan Pemungutan suara ulang pada 18 Distrik di Kabupaten Tolikara paling lama 60 (enam puluh) hari sejak Putusan ini.

(4) Memerintahkan KPU RI untuk melaksanakan Supervasi kepada KPU Provinsi Papua dalam penyelenggaraan pemungutan suara ulang.

(5) Memerintahkan kepada Bawaslu Provinsi Papua untuk melaksanakan pengawasan pada pelaksanaan Pemungutan suara ulang di 18 distrik.

(6) Memerintahkan kepada Bawaslu RI untuk melakukan Supervasi pada Bawaslu Provinsi Papua dalam penyelenggaraan pemungutan suara ulang.

(7) Memerintahkan kepada Kepolisian Republik Indonesia agar melakukan pengamanan pada pelaksanaan Pemungutan suara ulang di 18 Distrik

(8) Memerintahkan KPU Provinsi Papua untuk melaporkan kepada Mahkamah Konstitusi tentang hasil perolehan suara pada pelaksanaan Pemungutan suara ulang di 18 Distrik.

(9) Memerintahkan kepada KPU RI agar melaporkan kepada Mahkamah Konstitusi mengenai hasil Supervasinya tehadap KPU Provinsi Papua pada Penyelenggaraan Pemungutan suara ulang.

(10) Memerintahkan Bawaslu Provinsi Papua agar melaporkan Kepada Mahkamah Konstitusi tentang pengawasan hasil pemungutan suara ulang.

(11) Memerintahkan Bawaslu RI untuk memberikan laporan kepada Mahkamah Konstitusi tentang hasil Supervasinya terhadap Bawaaslu Provinsi Papua pada Penyelenggaraan Pemungutan suara ulang. 


\subsubsection{Ketentuan Pasal 158 atau Ambang Batas Pada Putusan Mahkamah Konstitusi}

Ketentuan Pada Pasal 158 Undang-Undang Nomor 10 Tahun 2016 mengatur tentang Pengajuan sengketa pemilihan Kepala daerah untuk Pemilihan Gubernur, Bupati dan Walikota, yang terbagi dalam dua ayat. Ayat (1) mengatur untuk pemilihan Gubernur, dan ayat (2) mengatur pengajuan sengketa untuk pemilihan Bupati/Walikota.

(1) Peserta Pemilihan Gubernur dan Wakil Gubernur dapat mengajukan Permohonan pembatalan penetapan hasil perhitungan suara dengen ketentuan.

a. Provinsi dengan jumlah penduduk sampai 2.000.000 (dua juta) jiwa, pengajuan perselisihan perolehan suara dilakukan jika terdapat perbedaan paling banyak sebesar 2\% (dua persen) dari total suara sah hasil perhitungan suara tahap akkhir yang ditetapkan oleh KPU provinsi

b. Provinsi dengan jumlah penduduk lebih dari 2.000 .000 (dua juta) jiwa, sampai dengan 6.000.000 (enam juta) jiwa pengajuan perolehan suara dapat dilakukan jika terdapat perbedaan paling banyak 1,5\% (satu koma lima persen) dari total suara sah hasil perhitungan suara tahap akhir yang ditetapkan oleh KPU Provinsi.

c. Provinsi dengan jumlah penduduk lebih dari 6.000 .000 (enam juta) jiwa sampai dengan 12.000.000 (dua belas juta) jiwa, pengajjuan perselisihan perolehan suara dilakukan jika terdapat perbedaan paling banyak sebesar $1 \%$ (satu persen) dari total suara sah hasil perhitungan suara tahap akhir yang ditetapkan oleh KPU provinsi

d. Provinsi dengan jumlah penduduk lebih dari 12.000 .000 (dua belas juta) jiwa, pengajuan perselisihan perolehan suara dilakukan jika terdapat perbedaan paling banyak sebesar 0,5\% (nol koma lima persen) dari total suara sah hasil perhitungan suara tahap akhir yang ditetapkan oleh KPU Provinsi

(2) Peserta pemilihan Bupati dan Wakil Bupati serta Walikota dan Wakil Walikota dapat mengajukan permohonan pembatalan penentapan hasil perhitungan perolehan suara dengan ketentuan.

a. Kabupaten/Kota dengan jumlah penduduk sampai dengan 250.000 (dua ratus lima puluh ribu) jiwa, pengajuan perselisihan perolehan suara dilakukan jika terdapat perbedaan paling banyak sebsar $2 \%$ (dua persen) dari total suara sah hasil perhitungan suara tahap akhir yang ditetapka oleh KPU Kabupaten/Kota.

b. Kabupaten/kota dengan jumlah penduduk lebih dari 250.000 (dua ratus lima pulu ribu) jiwa sampai dengan 500.000 (lima ratus ribu) jiwa, pengajuan perselisihan perolehan suara dilakukan apabila terdapat perbedaan paling banyak sebesar 1,,5\% (satu koma persen) dari total suara sah hasil perhitungan tahap askhir yang ditetapka oleh KPU Kabupaten/Kota. 
c. Kabupaetn/Kota dengan jumlah penduduk lebih dari 500.000 (lima ratus ribu) jiwa sampai dengan 1.000.000 (satu juta) jiwa, pengajuan perselisihan perolehan suara dilakuakn jika terdapat perbedaan paling banyak sebesar 1\% (satu persen) dari total suara sah hasil perhitungan suara tahap akshir yang ditetapkan oleh KPU kabupaten/Kota.

d. Kabupaetn/kota dengan jumlah penduduk lebih dari 1.000.000 (satu juta) jiwa,, pengajuan perselisihan perolehan suara dilakuakn jika terdapat paling banyak sebesar 0,5\% (nol koma lima persen) dari total suara sah hasil perhitungan suara tahap akhir yang ditetapkan KPU Kabupetan/Kota.

Ketentuan mengenai ambang batas pengajuan sengketa Pemilihan Kepala Daerah di Mahkamah Konstitusi juga diatur di dalam Peraturan MK Nomor 5 Tahun 2015 Tentang Perubahan Atas Peraturan MK Nomor 1 Tahun 1 Tahun 2015 Tentang Pedoman Beracara Dalam Perkara Perselisihan Hasil Pemilihan Gubernur, Bupati dan Walikota dalam Pasal 6 ayat (1) dan ayat (2).

Pada Pasal 158 ayat (2) huruf a " Kabupaten atau Kota dengan jumlah penduduk sampai dengan 250 (dua ratus lima puluh) jiwa, pengajuan perselisihan perolehan suara dilakukan jika terdapat perbedaan paling banyak $2 \%$ (dua persen) dari total perolehan suara sah hasil perhitungan tahap akhir yang di tetapkan oleh KPU Kabupaten atau Kota," dapat kita bandingkan dengan banyaknya penduduk Kabupaten Tolikara adalah 223.205 jiwa ${ }^{3}$. Jadi, jika melihat ketentuan Pasal 158 ayat (2) point a, dan Pasal 6 PMK Nomor 1-5/2015, maka Persentase perbedaan perolehan suara antara Pemohon atau Calon Nomor urut 3 dengan pasangan Calon Nomor urut 1 sebagai Pihak terkait untuk dapat diajukan permohonan perselisihan hasil pemilihan kepada Mahkamah Konstitusi adalah sebanyak $2 \%$.

Pada Keputusan KPU Tolikara Nomor 09/KPTS/KPU-Kab.TLK/II/2017 tentang penetapan Rekapitulasi Hasil Perhitungan Suara dan Hasil Pemilihan Bupati dan Wakil Bupati Tolikara Tahun 2017, pasangan Calon Nomor urut 1 Mendapatkan 118.640 suara, dan pasangan calon Nomor urut 2 adalah sebanyak 18.543 suara dan pasangan calon nomor urut 3 adalah 79.020. jika dihitung Calon Nomor urut 1 memeperoleh suara sebesar 118.640 suara sementara calon nomor urut 3 memperoleh 79.020 dan selisih suara adalah 39.620 .

Jika dikalkulasi atau dihitung, pasangan calon nomor urut 1 dengan perolehan suara 118.640, dan ketentuan selisih suara adalah 2\% maka, 2\% x jumlah pemilih : $2 \%$ $\mathrm{x} 216.203=4.325$. Oleh karena itu, yang berhak mengajukan permohonan dalam perkara ini berasarkan ketentuan Pasal 158 Undang-Undang Nomor 10 tahun 2016 dan Pasal 6 PMK 1-5/2015 adalah Pasangan calon dengan perolehan 4.325 suara. Akan tetapi, pasangan calon nomor urut tiga melebihi ambang batas sesuai ketentuan yang sudah diatur dengan selisih suara adalah 39.620 atau melebihi $2 \%$.

\footnotetext{
${ }^{3}$ Putusan Mahkamah Konstitusi No 14/PHP.BUP-XV/2017 Tentang Perselisihan Hasil Pemilihan Bupati dan Wakil Bupati Tolikara Provinsi Papua Tahun 2017.
} 
Ambang batas pengajuan sengketa ke Mahkamah Konstitusi menjadi syarat Administratif yang harus dipenuhi. Tetapi pada pelaksanaannya, Mahkamah Konstitusi tetap memeriksa sengketa Pilkada. Sengketa Pemilihan Bupati Kabupaten Tolikara, walaupun melebihi ambang batas tetap di periksa oleh Mahkamah Konstitusi. Sehigga pada sengketa ini, Mahkamah Konstitusi memberikan Putusan dan menganggap pemberlakuan Pasal 158 belum bisa di terapkan.

Pada sengketa Pemilihan Kepala Daerah Kabupaten Tolikara tahun 2017, Mahkamah Konstitusi justru menerima permohonan tersebut dan mengabulkan beberapa permohonan pemohon. Hal itu terlihat pada Putusan Sela yang di berikan oleh Hakim Mahkamah Konstitusi, seperti mebatalkan Putusan KPU Kabupaten Tolikara No 09/KPST/KAPUKab.TLK/II/2017 tentang Penetapan Hasil Perhitungan Suara dan Hasil Pemilihan Bupati dan Wakil Bupati Tolikara Tahun 2017 yang dinilai cacat hukum.

Penerapan ambang batas penyelesaian sengketa pemilihan kepala daerah atau penerapan ketentuan Pasal 158 Undang-Undang Nomor 10 Tahun 2016 pada Putusan Sela Mahkamah Konstitusi Nomor 14/PHP.BUP-XV/2017 oleh Mahkamah Konstitusi dikesampingkan melihat banyaknya pelanggaran yang terjadi. Namun pada Putusan Akhir Mahkamah Konstitusi tetap mempertimbangkan dan memberlakukan ketentuan ambang batas penyelesaian perselisihan hasil Pilkada. Hal itu di lakukan oleh Mahkamah Konstitusi setelah berlangsungnya pemilihan suara ulang di 18 Distrik di Tolikara, dan KPU Kabupaten Tolikara sudah menetapkan hasil rekapitulasi suara ulang.

\subsubsection{Pertimbangan Hukum Mahkamah Konstitusi Dalam Menerapkan Pasal 158 atau ketentuan Ambang batas}

Penerapan Ambang batas penyelesaian sengketa Pilkada tidak serta merta di berlakukan oleh Mahkamah Konstitusi. Pada Putusan Mahkamah Konstitusi bernomor 14/PHP.BUP-XV/2017, Mahkamah Konstitusi mengenyampingkan aturan Pasal 158. Hal itu sudah dijelaskan oleh Hakim Mahkamah Konstitusi pada pertimbangan Hukumya. Oleh karenanya penerapan tersebut tetap di serahkan sepenuhnya ke Mahkamah Konstitusi, dengan melihat fakta hukum di persidangan. Pada Pertimbangan Hukumnya, Hakim Mahkamah Konstitusi berpendapat bahwa, Mahkamah belum dapat memberikan penilaian atau pertimbangan apakah pemohon memenuhi ketentuan Pasal 158 Undang-Undang Nomor 10 tahun 2016 dan Pasal 7 PMK 1/2016 karena dalam persidangan di temukan fakta-fakta sebagai berikut : ${ }^{4}$

(1) Bahwa termohon telah mengeluarkan Keputusan KPU Kabupaten Tolikara Nomor 09/Kpts/KPU-Kab.TLK/II/Tahun 2017 tentang penetapan Rekapitulasi Hasil

\footnotetext{
${ }^{4}$ Putusan MK Nomor 14/PHP.BUP-XV/2017 Tentang Perselisihan Hasil Pemilihan Bupati dan Wakil Bupati Tolikara Provinsi Papua Tahun 2017
} 
Perolehan Suara dan Hasil Pemilihan Bupati dan Wakil Bupati Tolikara Tahun 2017.

(2) Bahwa terhadap Keputusan KPU Kabupaten Tolikara Nomor 09/Kpts/KPUKab.TLK/II/2017 sebagaimana tersebut pada angka 1 diatas, pemohon mengajukan permohonan pembatalan ke Mahkamah Kosntitusi sebagaimana tercatat dalam akta pengajuan permohonan pemohon nomor 39/PAN.MK/2007 yang disertai dengan bukti surat panitia Pengawasan Umum Kabupaten Tolikara Nomor 059/PNWSKAB-TLK/II/2017 perihal Rekomendasi Pembatalan Hasil Pemungutan Suara dan Pemungutan Sura Ulang pada Pemilihan Bupati dan Wakil Bupati Tolikara Tahun 2017.

(3) Bahwa rekomendasi Panitia Pengawasan Pemilihan Umum Kabupaten Tolikara sebagaimana tersebut pada angka 2 diatas memuat :

a) Rekomendasi kepada KPUD Tolikara untuk membatalkan hasil pemungutan suara dan penetapan perolehan suara

b) Merekomendasikan agar dilakukan Pemnugutan suara ulang pada 18 Distrik di Kabupaten Tolikara.

(4) Bahwa terhadap rekomendasi panitia pengawasan pemilihan umum Kabupaten Tolikara sebagaimana tersebut pada angka 3 diatas, Bawaslu RI menindaklanjuti dengan memberikan rekomendasi melalui surat nomor 0149/K.Bawaslu/PM.06.00/III/2017 Tentang Rekomendasi Bawaslu atas Pemungutan Suara Ulang (PSU) di Kabupaten Tolikara, yang isinya pada pokoknya meminta Kepada KPU untuk melakukan Hal-hal sebagai berikut:

a) Membatalkan Keputusan KPU Kabupaten Tolikara sepanjang menyangkut ditetapkan hasil perhitungan perolehan suara pada seluruh TPS di 18 Dsitrik sebagaimana yang dimaksud pada angka 3 huruf $b$ diatas.

b) Melakukan tindakan Korektif untuk memulihkan hak konstitusional yang terdaftar dalam DPT disemua TPS di 18 Distrik tersebut dengan melakukan pemungutan suara ulang.

c) Mengambil langkah-langkah hukum yang diperlukan sehubungan dengan pelaksanaan PSU disemua TPS pada 18 Distrik di Kabupaten Tolikara tersebut.

(5) Bahwa terhadap Rekomendasi Panwaslih Kabupaten Tolikara sebagaimana tersebut pada angka 2 diatas, dalam persidangan terungkap bahwa KPU Tolikara menolak melaksanakan Rekomendasi Panwaslih dimaksud dengan alasan Rekomendasi tersebut tidak dapat dibenarkan secara hukum karena tidak memenuhi kriteria sebagaimana yang dimaksud dalam Pasal 112 Undang-Undang Nomor 1 Tahun 2015 sebagaimana telah diubah dengan Undang-Undang Nomor 10 Tahun 2016 selain lewat waktu dan proses terbitnya rekomendasi Panwaslih tersebut tidak melalui prosedur. Namun menurut keterangan Panwaslih Kabupaten Tolikara dalam persidangan hari selasa 21 Maret 2017 rekomendasi Panwaslih tersebut telah 
diserahkan kepada KPU Kabupaten Tolikara melalui saudara Pilipus Samtai (Petugas keamanan di kantor KPU Kabupaten Tolikara) pada tanggal 17 Februari 2017, pukul 22.00 WIT, hal benar telah dibenarkan pula oleh termohon dalam persidangan yang sama, meskipun termohon menyatakan baru mengetahui keberadaan rekomendasi tersebut pada tanggal 18 februari 2017 pukul 09.00 WIT.

(6) Bahwa terhadap rekomendasi Bawaslu RI sebagaimana dimaksud pada angka 4 diatas, KPU RI melalui Komisioner Ida Budhiati menerangkan bahwa seharusnya KPU Kabupaten Tolikara melakukan Verifikasi, Klarifikasi, dan mencermati semua dokumen pendukung yang berkaitan dengan rekomendasi Panwaslih dan Bawaslu RI untuk mengambil kesimpulan dan menentukan sikap apakah akan menindaklanjuti atau tidak rekomendasi tersebut. Namun dalam hal ini KPU Kabupaten Tolikara telah menentukan sikap untuk tidak menindaklanjuti rekomendasi tersbut dengan alasan sebagaimana pada angka 5 diatas.

Berdasarkan pertimbangan dan fakta hukum diatas, kemudian Mahkamah Konstitusi belum serta merta memberlakukan ketentuan Pasal 158 tersebut. Hal ini juga dikarenakan penyelenggaraan Pemilihan Bupati dan Wakil Bupati Tolikara tahun 2017 banyak menyisahkan banyak persoalan pada proses pemungutan suara sampai pada rekapitulasi hasil pemilihan. Mahkamah Konstitusi juga berpendapat, pelaksaan rekapitulasi dinilai cacat hukum hal itu disebabkann karena pada pelaksanaan pemungutan suara sampai rekapitulasi tidak memenuhi ketentuan Peraturan Perundangundangan terutama dengan adanya rekomendasi Panwaslih Tolikara yang tidak dilaksanakan oleh KPU Kabupaten Tolikara.

Dari uraian diatas, dapat dilihat bahwa, berlakunya Pasal 158 Undang-Undang Nomor 10 Tahun 2016 berlaku pada permohonan yang sudah melakukan proses pemungutan suara dan rekapitulasi suara yang sesuai dengan ketentuan peraturan perundang-undangan dan dinilai tidak cacat hukum. Sementara pada permohonan yang pada berlangsungnya pemungutan suara dan rekapitulasi suara tidak cacat hukum dan memenuhi ketentuan peraturan perundang-undangan maka Undang-Undang Nomor 10 Tahun 2016 Pasal 158 tersebut belum diberlakukan. Selain itu, ada pula rekomendasi dari Bawaslu atau Panwaslu yang memutuskan bahwa dalam proses Pemungutan hingga rekapitulasi suara tersebut dinilai cacat hukum dan tidak memenuhi ketentuan peraturan perundang-undangan.

Rekomendasi Bawaslu atau Panwaslu menjadi pertimbangan Mahkamah Konstitusi dalam memberikan Putusan. Rekomendasi tersebut memiliki kekuatan Hukum, mengingat Bawaslu adalah lembaga pengawasan Pemilu, sehingga diakui keberadaan dan kewenangan Bawaslu dengan menjadikan rekomendasi Bawaslu sebagai pertimbangan Hakim Konstitusi. Hal yang tidak jauh juga di paparkan oleh Ketua Bawaslu RI Tahun 2008-2012, DR. Bambang Eka Cahya Widodo, S.IP., M.Si. yang menyatakan "bahwa rekomendasi memiliki kekuatan Hukum, selan itu, jika Mahkamah Konstitusi menjadikan Rekomendasi Bawaslu sebagai dasar pertimbangan 
dalam memberikan Putusan, artinya Bawaslu semakin di hargai dan hormati sebagai lembaga pengawasan Pemilu",

Menurut Pan Mohamad Faiz, Ph.D., berlakunya pengecualian atau pengenyampingan penerapan ambang batas dalam pemeriksaan senggketa Pemilihan Kepala Daerah adalah sebagai berikut ${ }^{6}$ :

a) Apabila pada penetapan rekapitulasi perolehan suara oleh KPU daerah berdasarkan pada rekapitulasi yang belum tuntas di hitung dari seluruh TPS yang ada.

b) Apabila adanya rekomendasi dari Panwaslu agar melaksanakan perhitungan suara atau pemungutan suara tidak dapat di tindaklanjuti oleh KPU daerah dengan dasar pertimbangan yang tidak memadai.

c) Jika KPU daerah melakukan suatu tindakan subordinasi dengan mengeluarkan keputusan atau tidak membatalkan keputusannya yang signifikan mempengaruhi keikutsertaan pasangan calon dalam Pemilihan kepala daerah serta menolak mengikuti rekomendasi yang dikeluarkan oleh KPU RI dan KPU Provinsi dan/atau Bawaslu RI dan Bawaslu Provinsi.

d) Apabila Mahkamah Konstitusi menemukan bukti awal jika terjadinya suatu permasalahan yang sangat mendasar dan krusial yang mengakibatkan ambang batas perolehan suara memiliki potensi menjadi tidak dapat dinilai atau dihitung.

Pada Putusan Akhir Mahkamah Konstitusi tetap mempertimbangakan ketentuan Pasal 158, mengingat telah diselenggarakan Pemilihan ulang di 18 Distrik. Oleh karena Mahkamah Konstitusi menilai rekapitulasi suara ulang yang di lakukan di 18 Distrik sesuai dengan ketentuan dan di nilai tidak cacat hukum. Hal itu menjadi dasar Mahkamah Konstitusi untuk memberlakukan ambang batas tersebut.

\subsection{Implikasi Penerapan Ambang Batas Sengketa Hhasil Pemilihan Kepala Daerah Oelh Mahkamah Konstitusi Terhadap Putusan MK Nomor 14/PHP.BUP-XV/2017}

Mahkamah Konstitusi merupakan lembaga kehakiman yang menjunjung tinggi penegakan hukum serta keadilan harus menjadikan hukum mempunyai relevansi yang kuat dengan keadilan. Hal ini meningat, sifat putusan Hakim Mahkamah Konstitusi yang final sehingga dalam memutuskan Mahkamah Konstitusi harus mengutamakan nilai-nilai keadilan. Sifat Putusan Mahkamah Konstitusi yang final, menjadikan Mahkamah Konstitusi sebagai lembaga yang Superbody, dimana Mahkamah Konstitusi memilki kekuasaan kelembagaan yang besar. Hakim dalam memutuskan suatu sengketa atau perkara tidak hanya manjadi terompet Undang-Undang semata, akan tetapi

\footnotetext{
${ }^{5}$ Wawancara dengan DR. Bambang Eka Cahya Widodo, S.IP., M.Si., Pada Tanggal 30 Agustus 2019, di UMY

${ }^{6}$ Mohamad Faiz, P. (2018), Kriteria Pengecualian Ambang Batas Sengekta Hasil Pilkada Di Mahkamah Konstitusi. Jakarta: Pusat Studi Konstitusi, h. 1671-1672
} 
seidealnya putusan tersebut sudah memperhatikan kesadaran hukum serta realitas di masyarakat. Oleh karenanya Mahkamah Konstitusi harus bisa memberikan Putusan yang seadil-adilnya.

Setiap putusan yang di putuskan oleh Hakim Mahkamah Konstitusi tentu memilki implikasi besar. Implikasi tersebut diantaranya bisa meliputi pada Penerapan sistem Hukum Indonesia. Penulis merangkum beberapa imlplikasi dari putusan Mahkamah Konstitusi tentang sengketa Pemilihan Bupati dan Wakil Bupati Kabupaten Tolikara.

\subsubsection{Mahkamah Konstitusi menjadi lembaga yang mengedepankan Keadilan Subtansif}

Keadilan subtansif yang dimaksud adalah suatu keadilan yang diciptakan oleh hakim pada segala putusannya yang berdasarkan hasil galiannya atas rasa keadilan di dalam masyarakat, serta tanpa dibelenggu ketentuan bunyi pasal undang-undang yang berlaku. Bentuk perbuatan yang sama namun bisa divonis secara berbeda, tergantung pada hasil galian hakim atas rasa dan dasar keadilan. Namanya pengadil, bukan penghukum ${ }^{7}$.

Kajian negara Hukum keadilan subtansif tidak berarti harus selalu mengabaikan ketentuan undang-undang, malainkan adanya keadilan subtansif berati hakim bisa mengabaikan ketentuan undang-undang yag tidak dapat memberikan keadilan, dan tetap berpedoman sesuai undang-undang atau prosedural yang sudah memberikan rasa keadilan dan menjamin kepastian hukum ${ }^{8}$.

Sedangkan dalam mencari dan memberlakukan keadilan substantif para hakim tidaklah cukup untuk berada pada batasan keadilan prosedural semata, melainkan harus dapat mewujudkan suatu keadilan yang sebenarnya, yang keadilan ini diperoleh dari penafsiran hakim dalam persidangan terhadap para pihak yang berperkara ${ }^{9}$. Penafsiran yang dilakukan oleh hakim Mahkamah adalah wujud kebebesan yang dimilikinya.

Menurut Ahmad Sodiki, penafsiran yuridis yang dilakukan oleh hakim Mahkamah Konstitusi saat menangani suatu sengketa, bukan hanya dalam bentuk penafsiran terhadap sumber yuridis yang dijadikan suatu pijakan atau rujukan rasionalitas terhadap sengketa yang diajukan oleh pemohon atau ketika sidang dilaksanakan, tetapi juga terhadap alat-alat dan/atau barang bukti. Dari penafsiran demikian ini kemudian dapat

\footnotetext{
7 Mahfud MD, M. (2014). Keadilan Subtansif, https://jurnaltoddoppuli.wordpress.com/2014/09/03/keadilan-substantif/ diakses pada tanggal 7 Juli 2019. ${ }^{8}$ Faqih, M. (2013). Konstruksi Keyakinan Hakim Mahkamah Konstitusi dalam Putusan Perselisihan Pemilukada, Pusat Kajian Konstitusi, Fakultas Hukum Universitas Islam Malang, h.133

${ }^{9}$ Arming. (2011). Urgensitas Penafsiran Hukum oleh http://armingsh.blogspot.com/2011/01/ugrensitas-penafsiran-hukum-oleh-hakim.html, diakses pada tanggal 7 Juli 2019.
} 
meyakinkan hakim agar menjatuhkan putusan atas sengketa Pilkada yang diperiksanya $^{10}$.

\subsubsection{Mahkamah Konstitusi dinilai tidak menjadi lembaga kalkulatif}

Implikasi dari Putusan Mahkamah Konstitusi Nomor 14/PHP.BUP-XV/2017 tentang sengketa Pemilihan Kepala Daerah Kabupaten Tolikara adalah Mahkamah Konstitusi dinilai tidak menjadi lembaga kalkulatif semata. Adanya Pasal 158 memberikan batasan persen untuk mengajukan sengketa Pilkada di Mahkamah Konstitusi, dan pasal tersebut di jadikan syarat administratif sebelum sengketa itu di sidangkan. Menurut ketua Komite Pemilih Indonesia (TePi), Jeirry Sumampow "Mahkamah Konstitusi tidak boleh lembaga Kalkulator, sebaliknya Mahkamah Konstitusi menjadi lembaga yang berbobot dalam penanganan sengketa Pemilihan Kepala Daerah ${ }^{11}$. Koordinator Nasional (KorNas) Jaringan Pendidikan Pemilih Untuk Rakyat (JPPR), Masykurudin Hafidz berpendapat, dalam memproses perkara sengketa Pemilihan Kepala Daerah secara utuh, Mahkamah Konstitusi bukan semata memproses persoalan perselisihan suara namun juga penyebab adanya perselisihan perolehan suara.

Putusan Mahkamah Konstitusi tentang sengketa Pemilihan Kepala Daerah Kabupaten Tolikara dapat mengubah stigma masyarakat yang menilai Mahkamah Konstitusi adalah lembaga kalkulatif. Karena dalam putusan tersebut Mahkamah Konstitusi mengenyampingkan Pasal 158 dan melihat pokok persoalan, sehingga dapat memutuskan dengan seadil-adilnya. Pada Putusan Mahkamah Konstitusi ini membuat Mahkamah Konstitusi membuka diri untuk lebih progresif dalam memutuskan sengketa Pemilihan Kepala Daerah, dan Mahkamah Konstitusi tidak dapat dikatakan lembaga yang kalkulatif dalam sengketa ini.

\subsubsection{Banyaknya peserta Pilkada mengajukan sengketa Pilkada di Mahkamah Konstitusi}

Menurut Pan Mohamad Faiz. Ph.D bahwa dengan kesadaran penuh, Mahkamah Konstitusi telah membuka ruang untuk mengenyampingkan ketentuan ambang batas pengajuan sengketa hasil Pilkada. Meski demikian, Mahkamah Konstitusi tetap perlu melakukan selektif dan penuh kehati-hatian dalam memeriksa perkara demi perkara ${ }^{12}$. Artinya adanya pengenyampingan Pasal 158 memberikan ruang bagi peserta Pilkada untuk mengaajukan sengketa ke Mahkamah Konstitusi.

\footnotetext{
${ }^{10}$ Faqih, M. (2013). Konstruksi Keyakinan Hakim Mahkamah Konstitusi dalam Putusan Perselisihan Pemilukada, Pusat Kajian Konstitusi, Fakultas Hukum Universitas Islam Malang, Malang, h.134.

${ }^{11}$ Hafidz, M. (2016). Mahkamah Konstitusi Bukan Mahkamah Kalkulator, https://www.hukumonline.com/berita/baca/lt56937c660474e/karena-mahkamah-konstitusi-bukanmahkamah-kalkulator, di akses pada tanggal 12 agustus 2019.

12 Mohamad Faiz, P. (2018). Efektifitas ambang batas sengketa hasil Pilkada, Jakarta: Pusat Kajian Konstitusi, hlm 79
} 
Dengan adanya Putusan Mahkamah Konstitusi ini, justru akan memberikan keyakinan bagi para pencari keadilan. Tingkat kepercayaan masyarakat terhadap Mahkamah Konstitusi sebagai lembaga penyangga keadilan tertinggi akan semakin tinggi, melihat Mahkamah Konstitusi yang dapat melakukan terobosan hukum. Banyaknya kekecewaan masyarakat karena Pasal 158 karena merasa dibatasi haknya untuk mencari keadilan di Mahkamah Konstitusi. Namun Mahkamah Konstitusi memberikan kabar baik bagi masyarakat sehingga dengan leluasa masyarakat dapat mengajukan sengketa ke Mahkamah Konstitusi.

\subsubsection{Mahkamah Konstitusi menjadi Lembaga yang menjaga marwah jalannya demokrasi}

Mahkamah Konstitusi adalah lembaga yang memeiliki peran untuk mengawal Konstitusi (the guardian of the constitution) dimana Konstitusi sebagai hukum tertinggi mengatur penyelenggaraan negara berdasarkan prinsip demokrasi dan hak-hak dasar manusia, dan menjamin perlindungan hak asasi manusia serta hak konstitusional warga negara. Mahkamah Konstitusi juga berfungsi sebagai pengawal demokrasi (the guardian of the democracy), pelindung hak konstitusional warga negara (the protector of the citizen's constitutional rights) serta pelindung hak asasi manusia (the protector of human rights). Di samping itu Mahkamah Konstitusi juga memiliki kewenangan dalam menentukan hukum (rechtvinding) dan bahkan membentuk hukum baru (rechtforming) wajib mengawal asas-asas dalam penyelenggaraan pemilihan umum yang diatur dalam Undang-Undang Dasar Negara Kesatuan Republik Indonesia Tahun 1945 Pasal 22 E ayat (1), bahwa pemilihan umum dilaksanakan secara langsung, umum, bebas, rahasia, jujur dan adil ${ }^{13}$.

Pada fungsinya sebagai pengawal demokrasi (the guardian of the democracy) Mahkamah Konstitusi memiki tanggung jawab untuk mengawal proses jalannya demokrasi di Indonesia Mahkamah Konstitusi menjadi penyangga upaya hukum terakhir bagi peserta Pemilihan Kepala Daerah yang merasa dirugikan hak-haknya, termasuk rakyat yang telah menjalankan haknya untuk memilih peserta Pemilihan Kepala Daerah. Peserta Pemilihan Kepala Daerah dan rakyat berhak mengajukan gugatan ke Mahkamah Konstitusi apabila ada hak demokrasi dan hak berpolitik dirugikan.

\subsubsection{Mahkamah Konstitusi melakukan penerobosan hukum}

Hakim Mahkamah Konstitusi secara yuridis dituntut untuk menunjukkan pikiran atau ide-ide yang berwujud penafsiran hukum disaat menangani masalah yuridis seperti

\footnotetext{
13 Sudrajat, H. (2010). Kewenangan Mahkamah Konstitusi Mengadili Perselisihan Hasil Pemilukada, jurnal Konstitusi, Mahkamah Konstitusi, h. 13
} 
yang seringkali ada dalam kasus sengketa Pilkada ${ }^{14}$. Akil Mochtar merupakan Hakim Mahkamah Konstitusi berpendapat, bahwa Mahkamah Konstitusi memiliki yurisprudensi yang digunakan dalam setiap putusan terkait dengan kompetensi Mahkamah Konstitusi dalam menangani PHPU atau pemilukada ${ }^{15}$.

Prof. Muhammad Mahfud MD, berpendapat bahwa hakim dalam melakukan pemeriksaan pada persidangan dan memberi suatu putusan, tidak hanya mengandalkan kecerdasan dan kecerdikan rasio semata, namun, hakim juga didukung kepekaan hati nuraninya sendiri, sehingga keputusannya dapat memberikan rasa keadilam, kemanfaatan serta mempunyai kepastian hukum ${ }^{16}$. Kebebasan Mahkamah Konstitusi dalam memutuskan suatu sengketa adalah jaminan yuridis dan hal ini tentu mendapatkan respon positif bagi masyarakat atau rakyat yang mencari keadilan (justiabelen) di Mahkamah Konstitusi.

Terobosan Hukum yang dilakukan Mahkamah Konstitusi pada putusan Mahkamah Konstitusi tentang sengketa Pemilihan Kepala Daerah Kabupaten Tolikara tentu memiliki pertimbangan. Adapun pertimbangan dari Mahkamah Konstitusi adalah terletak pada pertimbangan Hukum Mahkamah, dimana Mahkamah Konstitusi berpendapat Mahkamah belum serta merta memberlakukan Pasal 158 dan PMK 1/2017 karena penyelenggara pemilihan Bupati dan wakil Bupati Kabupaten Tolikara Tahun 2017 masih menyisahkan permasalahan dalam proses pemungutan suara hingga rekapitulasi suara. Sebab walaupun telah dilakukan rekapitulasi hasil pemilihan, namun Mahkamah menilai proses rekapitulasi suara tersebut dinilai cacat Hukum.

\section{Simpulan}

Penerapan ambang batas penyelesaian sengketa Pemilihan Bupati dan Wakil Bupati Kabupaten Tolikara oleh Mahkamah Kostitusi yang pada pemeriksaannya tidak mempertimbangkan secara langsung ketentuan ambang batas. Hal itu dikarenakan Mahkamah Konstitusi memberikan pengecualian ambang batas dengan cara mengenyampingkan penerapan ambang batas agar tercapainya rasa keadilan subtansif. Pengenyampingan ambang batas tersebut disebebkan oleh penyelenggaraan pemilihan bupati dan wakil bupati Tolikara menyisahkan banyak masalah dan rekapitulasi yang cacat hukum serta adanya Rekomendasi Bawaslu dan Panwaslu yang tidak dilaksanakan oleh KPU, sehingga di putuskan untuk melakukan pemilihan suara ulang. Pada Putusan Akhir barulah Mahkamah Konstitusi memberlakukan ketentuan ambang batas penyelesaian sengketa Pemilihan Kepala Daerah hal itu dikarenakan pelaksanaan

\footnotetext{
${ }^{14}$ Faqih, M. (2013). Konstruksi Keyakinan Hakim Mahkamah Konstitusi dalam Putusan Perselisihan Pemilukada, Pusat Kajian Konstitusi, Fakultas Hukum Universitas Islam Malang, h. 124

15 Mochtar, A. (2011). MK dan Perselisihan Hasil Pilkada", http://www.akilmochtar.com/wpcontent/uploads/2011/06/MK-dan-Perselisihan-Hasil-Pilkada.pdf, diakses 20 agustus 2019.

${ }_{16}$ Mahfud MD, M. (2012). Kata Sambutan Ketua MK RI, Dalam rangka Acara Final Debat Konstitusi Nasional di Jakarta, tanggal 25 Juni 2012, http://media.neliti.com/media/publications/109193-IDKonstiruksi-keyakinan-hakim-mahakah-kons.Pdf, Diakses pada tanggal 29 Agustus 2019.
} 
pemilihan pemungutan suara ulang di 18 Distrik berjalan sesuatu dengan Peraturan Perundang-Undangan dan tidak cacat hukum.

Pada penerapan ambang Batas pada Putusan MK nomor 14/PHP.BUP-XV/2107, Mahkamah Konstitusi mengnyampingkan terlebih dahulu ketentuan ambang batas, hal ini berimplikasi pada beberapa hal, Pertama, Lembaga Mahkamah Konstitusi menjadi lembaga yang mengedepankan Keadilan subtansif darri pada Ketentuan Prosedural. Kedua, Mahkamah Konstitusi dinilai tidak menjadi lembaga kalkulatif semata melainkan lebih mempertimbangkan pokok perkara. Ketiga, akan banyaknya peserta Pemilihan Kepala Daerah yang merasa di rugikan kemudian mengajukan sengketa Pilkada di Mahkamah Konstitusi. Keempat, Mahkamah Konstitusi menjadi Lembaga yang menjaga marwah jalannya demokrasi. Kelima adalah Mahkamah Konstitsi menjadi lembaga kehakiman yang melakukan penerobosan hukum.

\section{Daftar Pustaka}

\section{Buku}

Asshiddiqie, J. (2013). Pengantar Ilmu Hukum Tata Negara. Jakart: PT. Raja Grafindo Persada.

Fajar, M. dan Achmad, Y. (2010). Dualisme Penelitian Hukum Normatif dan Empiris. Yogyakarta: Pustaka Pelajar.

\section{Jurnal}

Sudrajat, H. ( 2010). Kewenangan Mahkamah Konstitusi Mengadili Perselisihan Hasil Pemilukada, jurnal Konstitusi, Mahkamah Konstitusi, Jakarta,

Faqih, M. (2013). Konstruksi Keyakinan Hakim Mahkamah Konstitusi dalam Putusan Perselisihan Pemilukada, Pusat Kajian Konstitusi, Fakultas Hukum Universitas Islam Malang,

Mohamad Faiz, P. (2018), Efektifitas ambang batas sengketa hasil Pilkada, Pusat Studi Konstitusi, Jakarta

Mohamad Faiz, P. (2018), Kriteria Pengecualian Ambang Batas Sengketa Hasil Pilkada Di Mahkamah Konstitusi, Pusat Studi Konstitusi, Jakarta, ,

\section{Regulasi (Undang-Undang Dan Putusan)}

Undang-Undang Dasar Negara Republik Indonesia Tahun 1945

Undang-Undang Nomor 8 Tahun 2015 Tentang Perubahan Atas Undang-Undang Nomor 1 Tahun 2015 Tentang Penetapan Peraturan Pemerintah Pengganti 
Undang-Undang Nomor 1 Tahun 2014 Tetang Pemilihan Gubernur, Bupati dan Walikota Menjadi Undang-Undang.

Undang-Undang Nomor 10 Tahun 2016 Tentang Perubahan Kedua Atas UndangUndang Nomor 1 Tahun 2015 Tentang Penetapan Peraturan Pemerintah Pengganti Undang-Undang Nomor 1 Tahun 2014 Tentang Pemilihan Gubernur, Bupati, dan Walikota Menjadi Undang-Undang.Peraturan Mahkamah Konstitusi Nomor 5 tahun 2015 Tentang Perubahan Atas Peraturan Mahkamah Konstitusi Nomor 1 Tahun 2015 Tentang Pedoman Beracara Dalam Perkara Perselisihan Hasil pemilihan Gubernur, Bupati dan Walikota

Putusan Mahkamah Konstitusi Nomor 14/PHP.BUP-XV/2017 tentang Perselisihan Bupati dan Wakil Bupati Tolikara Provinsi Papua

\section{Internet}

Mochtar, A. (2011). MK dan Perselisihan Hasil Pilkada. Diakses pada tanggal 20 Agustus 2019, http://www.akilmochtar.com/wp-content/uploads/2011/06/MKdan-Perselisihan-Hasil-Pilkada.pdf

Arming. (2012). Urgensitas Penafsiran Hukum oleh Hakim, diakses pada tanggal 7 juli 2019, http://armingsh.blogspot.com/2011/01/ugrensitas-penafsiran-hukum-olehhakim.html,

Mahfud MD, M. (2014), Keadilan Subtansif. Diakses pada tanggal 7 Juli 2019. https://jurnaltoddoppuli.wordpress.com/2014/09/03/keadilan-substantif/

Moh.Mahfud MD, Kata Sambutan Ketua MK RI, Dalam rangka Acara Final Debat Konstitusi Nasional di Jakarta tanggal 25 Juni 2012, diakses pada tanggal 29 Agustus 2019, http://media.neliti.com/media/publications/109193-ID-Konstiruksikeyakinan-hakim-mahakah-kons.Pdf

Hafidz, M. (2016). Karena Mahkamah Konstitusi Bukan Mahkamah Kalkulator Diakses pada 12 Tanggal Agustus 2019, https://www.hukumonline.com/berita/baca/lt56937c660474e/karena-mahkamahkonstitusi-bukan-mahkamah-kalkulator 